\title{
Reviews of Smallholder Farmers Market Participations Levels and It Determinant Factor in Ethiopia
}

\author{
Anuto David Ojulu \\ Lecturer in department of Agricultural Economic, Agricultural \\ and Natural Resources College, Gambella University
}

\begin{abstract}
In agrarian economy, empirical evidence of smallholder farmers' participation in the market has been extensively considered for variety of agricultural products. Smallholders' decision to participate in larger, more lucrative national or regional markets depends on the degree of constraints they face relative to the benefits they could derive from such participation and depends on their capacity to meet minimum production requirements, both in terms of quantities and product standards; it also requires that expected profits will be large enough to encourage them to produce. Improved market participation is a key precondition for transformation of the agriculture sector from subsistence to commercial production. Smallholder farming constitutes the livelihoods of many rural households in developing economies. Rural areas are the home of the majority in Africa and small scale agriculture is the mainstay of the rural economy serving mainly as a source of food income. Ethiopian economy is highly dependent on agricultural sector which account for about $38.8 \%$ of national GDP, $87 \%$ of export earnings and remains the main source of employment; generating $72.7 \%$ of total employment. Numerous factors are believed to have an influence on farmers' market participation decision. Such factors range from social-economic factors, institutional factors, market factors and external factors. Social-economic factors include age, gender, off-farm income, level of education, years of farming, household size, farm size and output level. Institutional factors entail membership to a group, access to extension services, access to credit, land tenure, infrastructure, contractual arrangements and, policies and law. Market factors such as access to market information, prices of output, distance to the market place, means of transport and other external factors such as natural calamities that result in crop failure also determines market participation by the crop farmers.
\end{abstract}

Keywords: level of market participations, determinant of market participations

DOI: $10.7176 / \mathrm{JPID} / 59-03$

Publication date: February $28^{\text {th }} 2021$

\section{Introduction of the reviews}

Smallholder farming constitutes the livelihoods of many rural households in developing economies. Rural areas are the home of the majority in Africa and small scale agriculture is the mainstay of the rural economy serving mainly as a source of food income (Omiti et al., 2007). Ethiopian economy is highly dependent on agricultural sector which account for about 38.8\% of national GDP (Wondifraw et al., 2016), 87\% of export earnings and remains the main source of employment; generating $72.7 \%$ of total employment (UNDP, 2015).

Improved market participation is a key precondition for transformation of the agriculture sector from subsistence to commercial production (Salami et al., 2010). Smallholder participation in food markets is typically characterized by constrained choice, and this choice is critically dependent upon their ability and willingness to participate in input and output markets and on the functionality of those markets that they are able to access. Smallholders are likely to increase their engagement in markets as sellers of food when well-functioning markets give them appropriate incentives, they have access to, and the ability to use assets productively, and efficient infrastructure allows them to transport their product to market at reasonable cost (Arias et al., 2013).

Being cognizant of role of market participation, has taken agricultural transformation as a means to tackle poverty and food insecurity problems through empowering smallholder farmers and pastoralists with tools, knowledge, and support needed to transition from a traditional subsistence orientation to one that is market focused and more commercialized (ATA, 2015). It is widely understood concept that, extent of income earning and the welfare status of smallholder farmers is determined by the extent they participate in a given market as seller. Therefore, study of these issues help to identify farm level factors and put forward measures for enhancing smallholders' market participation it will also contribute to food security and poverty reduction. Thus, this reviews aims to reveal status of smallholder farmers' market participation and identify determinant factors of smallholder farmers' market participation decision and level of market participation in market.

\section{Role of market participation}

There is general consensus that deeper market integration of smallholders is considered an important means of achieving food security status and to move out of poverty (Von Braun, 1995). Cognizant of this, recent studies and policy initiatives have focused on ways to enhance smallholder's agricultural productivity, and enable them to achieve greater market participation. Greater market participation is not an end goal, rather the ultimate of market 
participation is to bring the needed improvement of the welfare of society and enable them to sustainably progress out of the multifaceted poverty (Gutu, 2017).

According to Gutu (2017), welfare aspects are expressed through poverty, inequality and vulnerability. He represented welfare in terms of consumption of basic food (grains), high-value foods (livestock products) and expenditure on clothes and shoes, durable goods, education and healthcare in his analysis of welfare effects of market participation. In this context, those who have enough resources to meet their food needs are usually referred to as food secure. On the other hand, those with resources to meet both food and non-food needs are referred to as non-poor households (not in poverty class) and the converse is also true. In his empirical work, he found that positive relation between market participation and poverty status indicating that market participation enhances the welfare of participating households.

According to UNCTAD (2015), importance of smallholders' participation in markets is gauged by analyzing the extent to which they interact with input and output markets. Smallholders participate in markets either to buy food, procure inputs or sell their produce. The extent of smallholders' participation in input and output markets partly determines their productivity, and hence their earnings. Better linkages with markets can induce rural populations to consider farming as a profitable, and therefore a viable, livelihood choice. Participation in wellfunctioning agricultural input markets can enable farmers to increase yields, thus producing a marketable surplus, which, if sold in competitive output markets, can enable them to obtain higher prices and consequently increase their incomes. The resulting income is then used to buy consumer items that households need but cannot produce. This in turn improves their capacity to cope with risks and market instability.

Moreover, a study by Geoffrey et al, (2015) showed that greater market participation significantly reduces food insecurity and poverty among households with high market participation when compared against households with low market participation. Arias et al., (2013) in their report on smallholder's integration in changing food markets clearly explain that reducing poverty and enhancing food security require greater smallholder integration into markets and more inclusive value chains.

Factor affecting the market participation and decision at smallholder farmer.

In agrarian economy, empirical evidence of smallholder farmers' participation in the market has been extensively considered for variety of agricultural products. Smallholders' decision to participate in larger, more lucrative national or regional markets depends on the degree of constraints they face relative to the benefits they could derive from such participation and depends on their capacity to meet minimum production requirements, both in terms of quantities and product standards; it also requires that expected profits will be large enough to encourage them to produce (Arias et al., 2013).

Tollens (2006) emphasize that, while households whose food production hardly meets their consumption requirements are expected to have less degree of participation, incomes earned from marketing of produce may significantly facilitate input acquisition and hence increased productivity and in turn improve market participation. This means, market participation is said to be depend on levels of food production. Pender et al., (2006) stated as the development of input and output markets, institutions like property rights and land tenure, market regulations, cultural and social factors affecting consumption preferences, production and market opportunities and constraints, agro-climatic conditions, and production and marketing related risks and are other external factors that could affect the market participation and level of agricultural investment. Factors that affect market participation decision and extent of market participation are in respect to broad categorization of these factors into household (farmer) characteristics, private assets, public assets/social capital and transaction cost variables (Benjamin, 2013). A number of authors have studied these factors for various crops.

For instance, a study by Barett (2008) indicate that differential asset endowments, together with differential access to those public goods and services that facilitate market participation, are identified as important factors underlying heterogeneous market participation among smallholders. Transaction costs affect market participation by increasing household's cost that could arise due to lack of transport facilities. Moreover, numerous difficulties related to smallholders' access to input markets result in transaction costs that adversely affect the profitability of their participation in output markets, hence affect decision to participate in a given market for a particular crop (Arias et al., 2013). Also, the availability of market information plays an important role in their decision. Evidence on transaction cost indicates negative relationship between transaction costs and market participation (Alene et al., 2008). In this regard, the findings of Solomon et al., (2010) confirmed that, distance to main market variable is negatively correlated with marketed surplus because of the increased transaction costs associated with marketing of the farmers' agricultural produce. This is also related to access to improved seeds and other key agricultural inputs.

Numerous factors are believed to have an influence on farmers' market participation decision. Such factors range from social-economic factors, institutional factors, market factors and external factors. Social-economic factors include age, gender, off-farm income, level of education, years of farming, household size, farm size and output level. Institutional factors entail membership to a group, access to extension services, access to credit, land 
tenure, infrastructure, contractual arrangements and, policies and law. Market factors such as access to market information, prices of output, distance to the market place, means of transport and other external factors such as natural calamities that result in crop failure also determines market participation by the farmers.

Market participation of smallholder farmers is also affected by household's age, farm/marketing experience, and education level. Benjamin (2013) using double hurdle estimation found that, likelihood of participation in maize market negatively affected by age of household head, while sex of households negatively influenced extent of maize marketed. Numerous factors are believed to have an influence on farmers' market participation decision.

Such factors range from social-economic factors, institutional factors, market factors and external factors. Social-economic factors include age, gender, off-farm income, level of education, years of farming, household size, farm size and output level. Institutional factors entail membership to a group, access to extension services, access to credit, land tenure, infrastructure, contractual arrangements and, policies and law. Market factors such as access to market information, prices of output, distance to the market place, means of transport and other external factors such as natural calamities that result in crop failure also determines market participation by the crop farmers.

Tadele and Ashalata (2016) found that, experience in teff production increases quantity of teffsupplied to market indicating the importance of farm experience in a market participation analysis. According to Aman et al., (2014), education level of households motivate farmers market participation through improving the skill ability to utilize market information, which may in turn reduces marketing costs and make it more profitable to participate in the market. Firdisa (2016) also found as education level positively influence the likelihood of smallholder's participation decision. Lagged price also has an effect on altering households' production decision which in turn affects market participation decision and level of participation. Mebrahatom (2014) found that average annual selling price from previous year had positive effect on extent of teff sold. Also, Tadele and Ashalatha (2016) in their analysis of determinants of teff and wheat market supply revealed that lagged price determines the quantity of teff supplied to the market. This means, extent of market participation increases positively with lagged price. Access to credit also affects market participation as evidenced by literatures. Access to credit would enhance the financial capacity of the farmers to purchase the necessary inputs that are necessary for agricultural production which in turn enhance for market participation. Abafita et al., (2016) found that access to credit enhancing the probability of market participation significantly.

Asset holdings of household like oxen, land, farm implements and human capital is essential for marketable surplus production at smallholder level. Large farm size increases farmers' market participation because farmers having large farm size produce more output which increases a marketable surplus (Key et al., 2000).

Also, the findings by Geremew (2012) suggest that land is an important factor in influencing farmer's decision to produce any cash crop. Likewise, influence of land holding on likelihood of participation and intensity of marketed surplus clearly indicated in works by Efa et al., (2016). The availability of labor in a large amount for agriculture is another determinant of market participation. According to Osmani and Hossain (2015), household labor had positive and significant effect on smallholder's decision to participate in market indicating increase in household labor increases likelihood of market participation. Conversely, Adam and Dawit (2015) found negative effect of family size measured adult equivalent unit on smallholders' decision to participate in a market and intensity of market participation. This could be associated with consumption effect; as households with large family size retain significant portion of output for consumption. Gebreslassie et al., (2015) using Tobit estimation, they found distance to local market, lack of labor, age of household, expensive fertilizer, training on marketing, family size, farm size, outstanding debt, crop harvested in $\mathrm{kg}$, off farm income and draft power as significant variables influencing intensity of crop out market participation. Moreover, Ele et al., (2013) found that; total quantity of food crops produced, farming experience, access to agricultural extension service; size of land used for cultivation, membership in cooperatives and household family size are important factors determining the level of participation of smallholder farmers.

According to Tigist (2017), farm household's market participation decision and volume of crop sale are determined by access to improved inputs, farm size, output price, labor use, infrastructure facility, and livestock ownership. The land holding per household and availability of labor are the main factors of production that enable farm households to produce a surplus crop for market. Mignouna et al., (2016) using double hurdle model indicated that price and non-price constraints played significant roles in determining decisions on participation in maize and cow pea markets. Total farm size, price, and ease of transportation through access to motorized equipment were positively related to decision to participate in the maize market while volume of sale was affected by location. Age and total farm size positively related to decision to participate in the cow pea market while access to mobile phone, price and location affected volume of cow pea sold positively. Hlomendlini (2015) using double hurdle model sorted out factors affecting decision to participate in maize market.

According to his finding, gender of household head, household size, household land size, access to credit, government transfers affected likelihood of market participation positively. Intensity of maize sold was positively affected by household size, household land size, extension services, and fertilizer use. According to Moono (2015), 
decision to participate in rice market was positively affected by education level of household head, household size, output price, ownership of traction animal, ownership of working radio, price information, membership in farmer organization, and quantity of rice produced, while it was negatively affected by age of household. In his two step heckman estimation result, intensity of participation in rice market was affected by age of household head, size of land owned, access to credit facility, price information, membership in farmer organization, and quantity of rice produced. Abafita et al., (2016) using heckman estimation identified factors affecting market participation decision as; value of crop produced, any ox, number of adult family members, all weather road, access to credit, fertilizer use, cooperatives in peasant association were factors affecting market participation positively and age and family size were negatively affected market participation. According to their finding, level of participation was affected by value of crop produced, any ox, land, all weather road, access to credit, fertilizer use, market orientation index positively and by age and family size negatively. Alelign et al., (2017) used heckman two step estimation procedure to identify factors affecting decisions to participate in crop output market and level of participation. Their finding reveal that, farm households' decision to participate in crop output markets were influenced by sex of household head, farming experience, livestock holding, cultivated land size, off/non-farm income, fertilizer used, on-farm income, market distance, and crop diversification. On the other hand, dependency ratio, cultivated land size, education status, chemical fertilizer, and distance to market were factors influencing farm households' intensity of crop output market participation. Based on the above stated literatures, household (farmer) characteristics, private assets, public assets/social capital and transaction cost variables are also the focus of this review.

\section{Conclusion and Recommendations}

Factors that affect market participation decision and extent of market participation are in respect to broad categorization of these factors into household (farmer) characteristics, private assets, public assets/social capital and transaction cost variables. A number of authors have studied these factors for various crops.

Market participation of smallholder farmers is also affected by household's age, farm/marketing experience, and education level. market participation are negatively affected by age of household head, while sex of households negatively influenced extent of maize marketed. Numerous factors are believed to have an influence on farmers' market participation decision. Such factors range from social-economic factors, institutional factors, market factors and external factors. Social-economic factors include age, gender, off-farm income, level of education, years of farming, household size, farm size and output level. Institutional factors entail membership to a group, access to extension services, access to credit, land tenure, infrastructure, contractual arrangements and, policies and law. Market factors such as access to market information, prices of output, distance to the market place, means of transport and other external factors such as natural calamities that result in crop failure also determines market participation by the crop farmers.

\section{References}

1 Abafita, J., Atkinson, J. and Kim, C.-S. 2016. Smallholder commercialization in Ethiopia: market orientation and participation. International Food Research Journal. 23(4): 1797-1807.

2 Adam Bekele and Dawit Alemu. 2015. Farm-level determinants of output commercialization: In haricot bean based farming systems. Ethiop. J. Agric. Sci. 25: 61-69.

3 Alelign Ademe, Belaineh Legesse, Jema Haji, Degye Goshu. 2017. Smallholder farmers' crop commercialization in the highlands of eastern Ethiopia. Review of Agricultural and Applied Economics, 20(2): 30 - 37.

4 Alene, A. D., Manyong, V.M., Omanya, G., Mignouna, H.D., Bokanga, M. and Odhiambo, G. 2008. Smallholder market participation under transactions costs: Maize supply and fertilizer demand in Kenya. Food Policy, 33 : $318-28$.

5 Aman Tufa, Adam Bekele, and Lemma Zemedu. 2014. Determinants of smallholder commercialization of horticultural crops in Gemechis district, West Hararghe zone, Ethiopia. African Journal of Agricultural Research, 9(3): 310-319.

6 Arias, P, Hallam, D, Krivonos, E and Morrison, J. 2013. Smallholder integration in changing food markets: Food and Agriculture Organization of the United Nations, Rome.

7 ATA (Agricultural Transformation Agency). 2015. Annual report on agricultural transformation agenda.

8 Barrett, C. 2008. Smallholder market participation: Concepts and evidence from eastern and southern Africa. Food Policy, 34: 299-317.

9 Benjamin A. 2013. Market participation of smallholder farmers in the Upper West region of Ghana. MSc. Thesis submitted to University of Ghana, Legon.

10 Efa Gobena, Degye Goshu, Tinsae Demisie, and Tadesse Kenead. 2016. Determinants of market participation and intensity of marketed surplus of teff producers in Bacho and Dawo districts of Oromia State, Ethiopia. Journal of Economics and Sustainable Development, 7(1): 2222-1700.

11 Ele, I. E., Omini, G. E., Adinya, B. I. 2013: Assessing the extent of commercialization of smallholding farming 
households in cross river state, Nigeria, IOSR Journal of Agriculture and Veterinary Science (IOSR-JAVS), pp. 49-55.

12 Firdisa Birru. 2016. Determinants of smallholder farmers' participation decision in teff production: Evidence from Horo and Jimma Geneti Woreda, Ethiopia. Developing Country Studies, 6(10): 2224-607.

13 Gebreslassie Hailua, Kebede Manjureb and Kiros-Meles Aymutc. 2015. Crop commercialization and smallholder farmers' livelihood in Tigray region, Ethiopia. Journal of Development and Agricultural Economics, 7(9): 314-322.

14 Geoffrey S. Muricho, Damiano K. Manda and Fredrick O. Sule. 2015. 'Determinants of agricultural commercialization and its impacts on welfare among smallholder farmers in Kenya'. Published $\mathrm{PhD}$ dissertation, Nairobi, Kenya.

15 Geoffrey S. Muricho, Damiano K. Manda and Fredrick O. Sule. 2015. 'Determinants of agricultural commercialization and its impacts on welfare among smallholder farmers in Kenya'. Published $\mathrm{PhD}$ dissertation, Nairobi, Kenya.

16 Geremew Kefyalew. 2012. Analysis of smallholder farmer's participation in production and marketing of export potential crops: The case of sesame in Diga district, east Wollega zone of Oromia Regional State. An MSc Thesis presented to the Addis Ababa University, Addis Ababa, Ethiopia.

18 Key, N., Sadoulet, E. and de Janvry, A. 2000. Transactions costs and agricultural household supply response. American Journal of Agricultural Economics, 82(2): 245- 59.

19 Mignouna B.M., Abdoulaye T., Akinola A.A., Kamara A.Y., and Olouch M. 2016. Understanding market participation choices and decisions of maize and cow pea farmers in Northern Nigeria. Tropicultura, 34(1): 26-29.

20 Moono L. 2015. An analysis of factors influencing market participation among smallholder rice farmers in Western Province, Zambia. An MSc. thesis submitted to University of Nairobi, Nairobi.

21 Osmani $G$, and Hossain E. 2015. Market participation decision of smallholder farmers and its determinants in Bangladesh. Economics of Agriculture. UDC: 631.1.017.3:339.3 (549.3).

22 Salami, A., Kamara, A. B. and Brixiova, Z. 2010. Smallholder agriculture in East Africa: Trends, constraints and opportunities. Working Papers Series No. 105, African Development Bank, Tunis, Tunisia.

23 Tadele Melaku And Ashalatha, D. 2016. Determinants of teff and wheat market supply in Dendi district, West Shoa zone, Ethiopia. International Journal of Current Research, 8(10): 40716 - 40721.

24 Tigist Mekonnen. 2017. Agricultural intensification and market participation small-scale agriculture, Maastricht University and UNU-MERIT.

25 Tollens, E. F. 2006. Market information systems in sub-Sahara Africa challenges and opportunities. Poster paper prepared for presentation at the International Association of Agricultural Economists Conference, Gold Coast, Australia.

26 UNCTAD (United Nations Conference on Trade and Development). 2015. Smallholder farmers and sustainable commodity development. Commodities and development report, New York and Geneva.

27 UNDP (United Nations Development Programme). 2015. Ethiopia: Key economic and social indicators. UNDP Ethiopia's Policy Advisory Unit, No. 2.

28 Von Braun, J. 1995. Agricultural commercialization: Impacts on income and nutrition and implications for policy. Food Policy, 20(3): 187-202.

29 Wondifraw Zerihun, James Wakiaga, and Haile Kibret. 2016. African Economic Outlook, Ethiopia. 